\title{
IMPLEMENTASI PENDIDIKAN KEPENDUDUKAN DAN REPRODUCTION HEALTH DALAM MENDUKUNG SEKOLAH SIAGA KEPENDUDUKAN DI KABUPATEN MALANG
}

\author{
Ifan Deffinika, Alfyananda Kurnia Putra*, Nailul Insani, Muhammad Naufal Islam, Muhammad \\ Rafi' Attamimi, Anditya Bagus Krisna Mukti \\ alfyananda.fis@um.ac.id
}

Jurusan Geografi, Fakultas IImu Sosial, Universitas Negeri Malang

Diterima 8 September 2020, dipublikasikan 31 Oktober 2020

\begin{abstract}
Abstrak
Remaja dalam sudut pandang kependudukan termasuk ke dalam kelompok rentan, memiliki rasa ingin tahu yang tinggi. Sebaliknya remaja merupakan investasi suatu negara, mengingat remaja merupakan subjek dan objek dalam pembangunan. Kondisi demikian membutuhkan suatu langkah strategis dalam mengatasi permasalahan, salah satunya melalui membangun Sekolah Siaga Kependudukan. Tujuan dari kegiatan ini untuk meningkatkan kompetensi dan pengahuan, sikap dan keterampilan dalam Pendidikan kependudukan. Kegiatan pengabdian dihadiri siswa-siswa pilihan di MA Al-Ittihad, dengan dua kegiatan utama yaitu sosialisasi dan pelatihan. Program pengabdian masyarakat ini menekankan pada metode ceramah, diskusi, dan demonstrasi. Hasil dari kegiatan pengabdian Pendidikan Kependudukan dirasakan oleh siswa melalui bertambahnya kompetensi kognitif dan psikomotorik siswa. Pada ranah kognitif, partispan memperoleh pengetahuan baru berupa wawasan dan gambaran kondisi kependudukan Indonesia.
\end{abstract}

Kata Kunci: Pendidikan Kependudukan, Reproduction Health, Sekolah Siaga Kependudukan

\section{PENDAHULUAN}

Remaja dalam sudut kependudukan termasuk ke dalam kelompok rentan. Remaja dengan rentang usia 13-19 tahun (Steeg et al., 2020) rentan terhadap berbagai pengaruh negatif yang didominasi dengan perilaku menyimpang (Demir-Dagdas, 2020; Menéndez Santurio et al., 2020) Kondisi demikian menyebabkan remaja dihadapkan pada berbagai permasalahan kompleks. Pada proses pertumbuhan dan perkembangannya, remaja dihadapkan pada berbagai permasalahan. Permasalahan seperti Isu tentang karakter, mental dan moral, serta seks pra-nikah menjadi problematika kompleks bagi remaja (Paolini, 2019). Kondisi demikian sangat memprihatinkan, mengingat remaja sebagai salah satu subjek dan objek dalam pembangunan (Zangiacomi Martinez \& da Roza, 2020). Selain itu, karakteristik keruangan juga berdampak pada pola permasalahan remaja (Lestari, 2012), tak terkecuali pada daerah pedesaan.

Tantangan yang dihadapi remaja di daerah pedesaan semakin besar. Besarnya kesenjangan antar wilayah menyebabkan semakin meningkatnya daya dorong dan penarik pada suatu wilayah (He et al., 2019). Keterbatasan pada berbagai sarana publik (ekonomi, kesehatan, dan pendidikan) menjadi faktor dalam permasalahan remaja (Binik et al., 2019). Remaja dengan rasa keingintahuan tinggi pada wilayah pedesaan akan mudah terjerumus pada permasalahan remaja (Murry et al., 2020). Permasalahan seperti pernikahan usia dini dan kesehatan reproduksi menjadi permasalahan utama remaja desa (Mochaoa Rogers et al., 2019). Berdasarkan pernyataan demikian maka diperlukan langkah strategis sebagai upaya dalam meminimalisir permasalahan remaja di dearah pedesaan, salah satunya melalui pendidikan kependudukan.

Jurusan Geografi, dengan kajian pada bidang fisik, humaniora, serta hubungan timbal balik diantara keduanya memiliki peran penting terhadap pendidikan kependudukan. Pendidikan kependudukan dapat terrealisasi melalui kegiatan pengabdian kepada masyarakat sebagai wujud dari Thridharma Perguruan Tinggi, Universitas Negeri Malang. Kegiatan pengabdian ini dilaksanakan 
sebagai media bagi akademisi dalam berkontribusi secara aktif melalui implementasi teori dalam menjawab permasalahan pada lingkungan masyarakat.

Kegiatan pengabdian masyarakat jurusan Geografi bertujuan untuk implementasi praktis bidang keilmuan pada lingkungan masyarakat. Pengabdian dilakukan dengan menekankan pada kegiatan sosilalisasi sebagai transfer of knowledge kepada masyarakat dan pelatihan sebagai media dalam implementasi informasi baru. Melalui dua kegiatan ini, diharapkan kegiatan pengabdian dapat menjembatani bidang keilmuan akademisi dalam mengatasi dan memberikan solusi efektif pada kehidupan masyarakat. Sasaran mitra dalam kegiatan pengabdian masayarakat ini adalah remaja pada sekolah MA Al-Ittihad, Kecamatan Poncokusumo, Kabupaten Malang. Kegiatan pengabdian ini dihadiri oleh 40 siswa-siswi pilihan lintas jurusan MA Al-Ittihad. Kondisi sosial demografi partispan beragam baik jenis kelamin, usia, tingkatan (kelas), hingga jurusan.

Berdasarkan studi lapangan dan wawancara kepada guru dan kepala sekolah menyatakan bahwa sebagian besar tren permasalahan remaja pada MA Al-Ittihad siswa setelah menempuh pendidikan sekolah menengah melakukan pernikahan. Kondisi demikian akan berdampak pada tingginya angka pernikahan dini dan kesehatan reproduki remaja pada sekolah (Isnaini \& Sari, 2019). Mengingat keterbatasan pada berbagai akses publik baik ekonomi, kesehatan, dan pendidikan memambah permasalahan yang dihadapi remaja seperti pengangguran dan berdampak pada kenakalan remaja lainnya. Berdasarkan permasalahan yang telah diungkapkan, maka program pengabdian masyarakat ini menekankan pada sosialissasi dan implementasi pendidikan kependudukan pada remaja melalui pelatihan dalam menjawab permasalahan kependudukan di MA Al-Ittihad, Kecamatan Poncokusumo, Kabupaten Malang. Melalui kegiatan ini, diharapkan partisipan memiliki gambaran mengenai pentingnya pendidikan kependudukan bagi remaja serta softskill sebagai upaya efektif menghambat usia pernikahan yang berdampak pada terjaganya kesehatan reproduksi remaja.

\section{METODE}

Implementasi kegiatan pengabdian ini dikemas dalam sebuah pelatihan (Wiradimadja et al., 2019). Metode yang digunakan yaitu ceramah, diskusi, dan demonstrasi. Metode ceramah memiliki kelebihan yakni tidak banyak memerlukan peralatan laboratorium dan bersifat direct instruction dapat membangkitkan kognitif dan aktivitas siswa (Zahriani, 2014). Penggunaan metode ceramah diintegrasikan dengan jenis pertanyaan divergen dan konvergen untuk membangun interaksi antara pemateri dan peserta pelatihan. Sedangkan, metode demonstrasi digunakan sebagai upaya memberikan gambaran secara nyata kepada peserta dengan objek yang sebenernya (Sulfemi, 2018). Selain itu, pemateri mengutamakan penjelasan yang kongkrit dan mengindari verbalisme sehingga penjelasan lebih menarik dan memotivasi.

Kegiatan pengabdian kepada masyarakat dilaksanakan di MA Al-Ittihad Kecamatan Poncokusumo, Kabupaten Malang. Kegiatan ini dilaksanakan dua hari pada tanggal 22-23 Agustus 2020, dengan khalayak sasaran yakni guru Pembina Kegiatan Siswa (PKS) dan siswa pilihan di MA AlIttihad berjumlah 40 siswa. Pada hari pertama atau Sabtu, 22 Agustus 2020, menekankan pada kegiatan sosialisasi pentingnya pendidikakan kependudukan untuk remaja berencana. Tujuan dari sosialisasi ini sebagai upaya memberikan gambaran awal kepada peserta dan memotivasi peserta untuk memunculkan sikap inkuiri terhadap materi yang disampaikan. Hal ini penting dilakakukan sebagai upaya penyamaan persepsi antara pemateri dan peserta, mengenai permasalahan kependudukan yang bersifat strategis, universar dengan spektrum yang luas.

Hari kedua atau Minggu, 23 Agustus 2020, kegiatan pengabdian kepada masyarakat berfokus pada kegiatan pelatihan. Pokok materi yang disampaikan menekankan pada Opportunities And Challenges: Towards the 2030 Indonesia Demography Bonus dan Penggunaan Web-GIS Kependudukan. Hari kedua ini, pemateri menggunakan metode demonstrasi. Melalui demonstrasi partisipan diberikan kesempatan sebesar-besarnya dalam mengaplikasikan informasi dan pengetahuan baru yang telah didapatkan sebelumnya. 
Tabel 1. Materi Pendidikan Kependudukan

\begin{tabular}{|c|c|c|c|}
\hline No & Materi & Tujuan & Deskripsi Kegiatan \\
\hline 1 & $\begin{array}{l}\text { Paradigma Pendidikan } \\
\text { Kependudukan di } \\
\text { Indonesia }\end{array}$ & $\begin{array}{l}\text { Memberikan pengantar kepada } \\
\text { partisipan kondisi kependudukan di } \\
\text { Indonesia. Pemberian pengantar } \\
\text { dan penyamaan persepsi demikian } \\
\text { dapat membuka wawasan } \\
\text { partisipan mengenai konten materi } \\
\text { yang disampaikan dalam kegiatan } \\
\text { pengabdian. }\end{array}$ & $\begin{array}{l}\text { Penyajian materi } \\
\text { melalui metode } \\
\text { ceramah dan tanya } \\
\text { jawab. }\end{array}$ \\
\hline 2 & $\begin{array}{l}\text { Kesehatan Reproduksi } \\
\text { Generasi Z }\end{array}$ & $\begin{array}{l}\text { Perserta memiliki pengetahuan } \\
\text { Kesehatan reproduksi sehingga } \\
\text { berpengaruh terhadap peningkatan } \\
\text { angka pernikahan dan Kesehatan } \\
\text { kehamilan pada usia remaja. }\end{array}$ & $\begin{array}{l}\text { Penyajian materi } \\
\text { melalui metode } \\
\text { ceramah, diskusi dan } \\
\text { tanya jawab. }\end{array}$ \\
\hline 3 & $\begin{array}{l}\text { Remaja Generasi } \\
\text { Berencana (GenRe) }\end{array}$ & $\begin{array}{l}\text { Memberikan penguatan } \\
\text { pengetahuan mengenai kedudukan } \\
\text { remaja dalam membangun } \\
\text { Generasi berencana Indonesia. } \\
\text { Selain itu, pada penyajian materi } 2 \\
\text { ini dihadiri oleh Duta GenRe } \\
\text { sebagai role model bagi peserta. }\end{array}$ & $\begin{array}{l}\text { Penyajian materi } \\
\text { melalui metode } \\
\text { ceramah dan sesi } \\
\text { tanya jawab. }\end{array}$ \\
\hline 4 & $\begin{array}{l}\text { Opportunities And } \\
\text { Challenges: Towards The } \\
2030 \text { Indoneisa } \\
\text { Demography Bonus }\end{array}$ & $\begin{array}{l}\text { Memberikan pengalaman autentik } \\
\text { bagi partisipan dalam belajar } \\
\text { mengenai peluang dan tuntutan } \\
\text { kependudukan Indonesia tahun } \\
\text { 2030. Demonstrasi dan praktik } \\
\text { dilakukan untuk menguatkan dan } \\
\text { mengimplementasikan konsep } \\
\text { yang telah dipaparkan sebelumnya. }\end{array}$ & $\begin{array}{l}\text { Penyajian materi } \\
\text { melalui metode } \\
\text { demonstrasi dan } \\
\text { praktek serta sesi } \\
\text { tanya jawab }\end{array}$ \\
\hline 5 & $\begin{array}{l}\text { Penggunaan Web-GIS } \\
\text { Kependudukan sebagai } \\
\text { Sumber Data } \\
\text { Kependudukan dan } \\
\text { Analisis Data } \\
\text { Kependudukan }\end{array}$ & $\begin{array}{l}\text { Memberikan pengalaman dan } \\
\text { pemahamn penggunaan Web-Gis } \\
\text { Kependudukan untuk analisis data } \\
\text { kependudukan }\end{array}$ & $\begin{array}{l}\text { Penyajian materi } \\
\text { melalui metode } \\
\text { demonstrasi dan } \\
\text { praktek serta sesi } \\
\text { tanya jawab }\end{array}$ \\
\hline
\end{tabular}

\section{HASIL DAN PEMBAHASAN}

Pelaksanaan sosialisasi dan implementasi program ini dilaksanakan selama dua hari dengan jumlah bobot materi sebanyak 20 jam. Pendekatan pelatihan menekankan pada ranah kognitif, afektif dan psikomotorik sehingga memberikan pembelajaran yang bermakna bagi peserta. Kurikulum pelatihan dikembangkan berdasarkan aspek kompetensi, peserta, pelaksanaan dan evaluasi (Widoyoko Tayibnapis, 2000). Dalam pelaksanaan program ini, melibatkan 4 pemateri yakni Alfyananda Kurnia Putra, M.Pd, Ifan Deffinika, M.Sc, Syahroni Al-Khadir, Daniar Arshita.

Materi pertama yang disajikan yakni Paradigma Pendidikan Kependudukan di Indonesia. Pada sesi ini disampaikan urgensi Pendidikan kependudukan untuk menyelesaian permaslaahan kependudukan mulai dari fertilitas, mortalitas hingga migrasi yang bersifat strategis dan sangat penting. Berdasarkan jumlah penduduk, Indonesia dihadapkan pada peluang dan ancama dalam pembangunan dan pertumbuhan (Rimmer et al., 2013). Bertambahnya penduduk berimplikasi pada persaingan kerja dan kualitas sumber daya yang dihasilkan (Chapman et al., 2011). Selain itu, juga sangat berkaitan dengan daya dukung lingkungan sebagai tempat tinggal. 


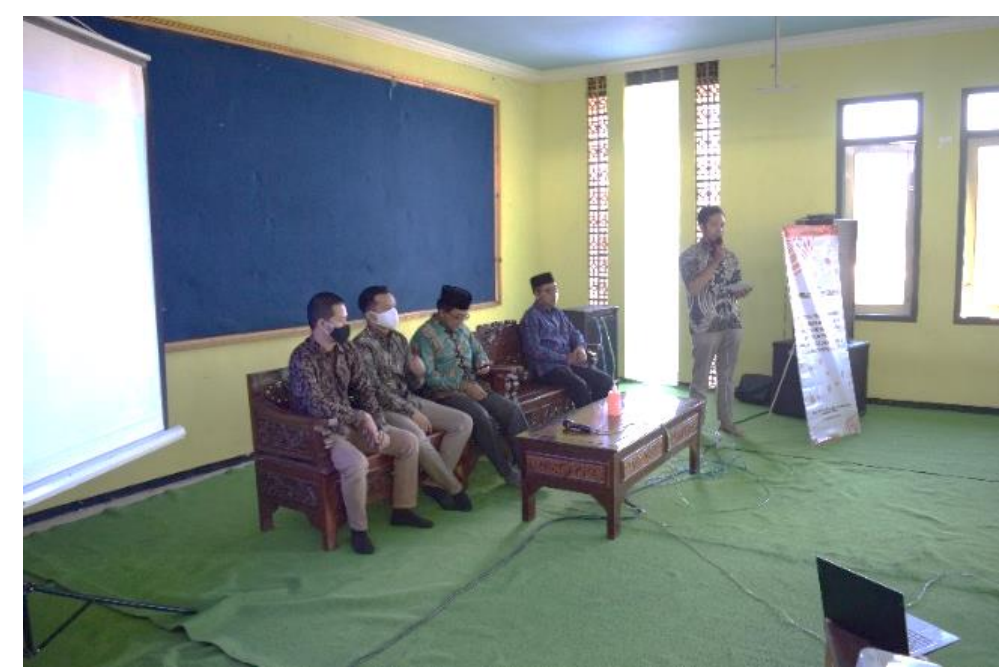

Gambar 1 Pembukaan dan Penyampaian materi Paradigma Pendidikan Kependudukan di Indonesia

Materi kedua, disampaikan oleh Ifan Deffinika, M.Sc dengan materi Kesehatan Reproduksi Generasi Z. Pendidikan kesehatan reproduksi memberikan wawasan kepada peserta untuk membangun sikap positif dimulai dari diri sendiri mengenai permasalahan seksualitas dan reproduksi (lyer \& Aggleton, 2013). Penyampaian materi ini diharapkan membentuk sikap tanggung jawab terhadap perilaku remaja dan menghindari perilaku menyimpang (Pandey et al., 2019).

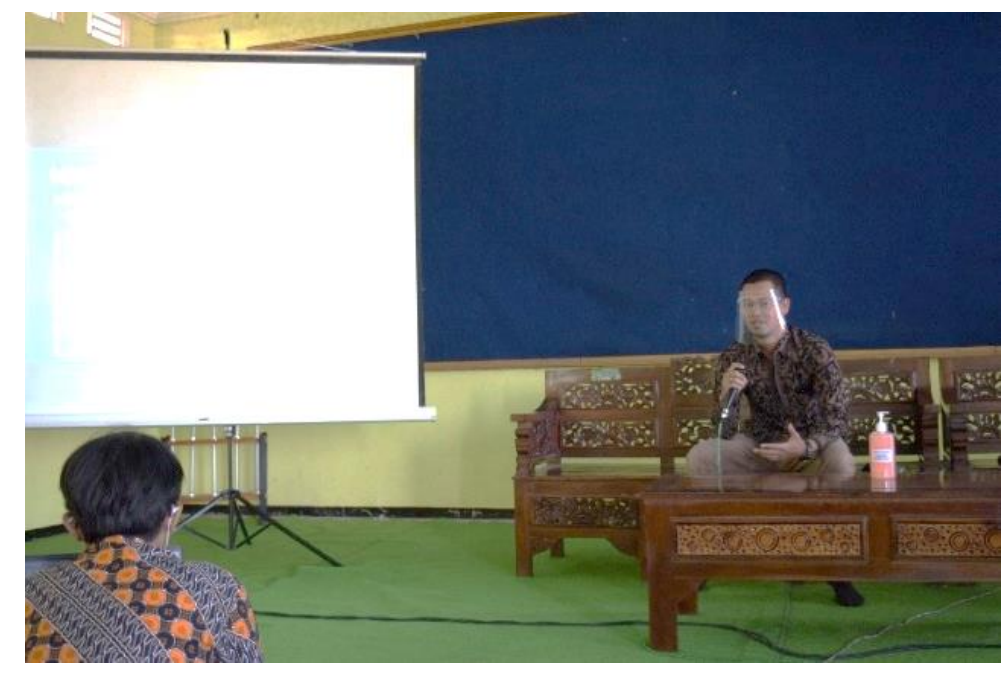

Gambar 2 Pemaparan Materi oleh Ifan Deffinika S.Si, M.Sc

Kesehatan reproduksi merupakan layanan Kesehatan reproduksu kepada masyarakat bersifat individu dan keluarga secara komperhensif. Hal ini bertujuan, mendapatkan proses reproduksu yang sehat dan bertanggung jawab serta mempersiapkan mental, agar siap mengadapi situasi sulit dalam rumah tangga (Santhya \& Jejeebhoy, 2015). Tim kurikulum pelatihan mempertimbangkan bahwa remaja harus mengetahui risiko pernikahan dini, kehamilan terlalu muda, dan aborsi. Sehingga, remaja memiliki harapan yang besar untuk mendapatkan kualitas hidup dan keturunan yang baik.

Materi ketiga yakni Remaja Generasi Berencana (GenRe) yang disampaikan oleh Syahroni Alkhadir yang merupakan Duta GenRe. Materi yang disampaikan meliputi : Program GenRe, Tujuan GenRe, Strategi GenRe, Mempersiapkan masa depan dengan rencana. Materi ini membentuk remaja yang memiliki arakter untuk menjahui seks pra-nikah, NAPZA dan remaja yang memiliki rencana untuk masa depanya sebagai upaya berkontribusi dalam pembangunan masyarakat yang unggul. 


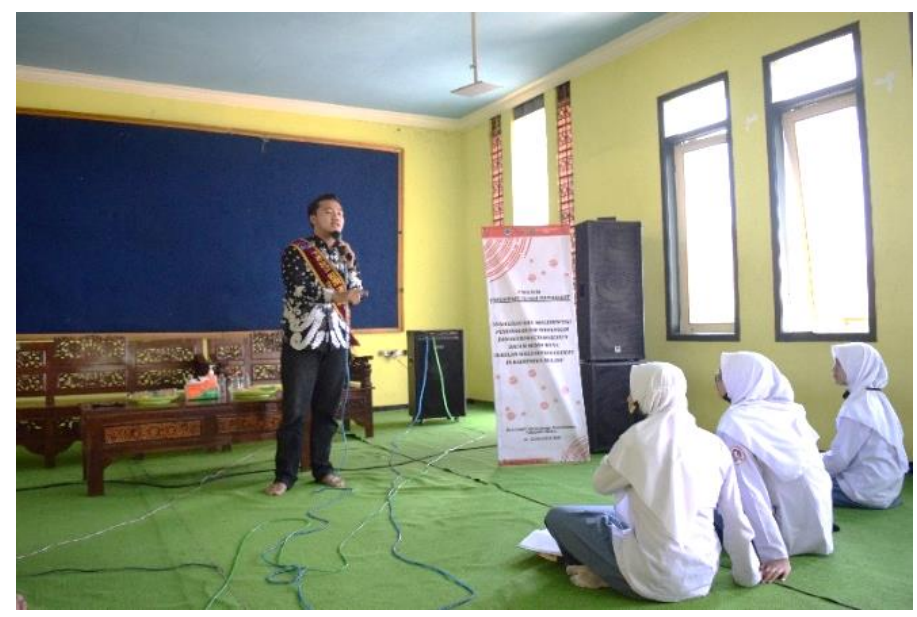

Gambar 3 Pemaparan Materi oleh Duta GenRe yakni Syahroni Al Khadzira

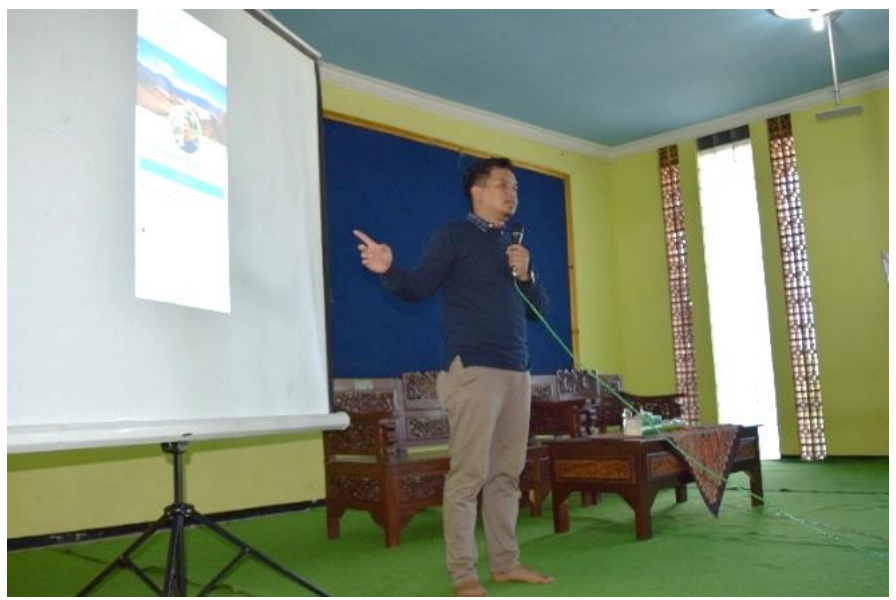

Gambar 4 Pemaparan Materi oleh Alfyananda Kurnia Putra S.Pd, M.Pd

Materi terakhir disampaikan oleh Alfyananda Kurnia Putra, M.Pd yakni tantangan Indonesia menghadapi bonus Demografi dan Penggunaan Web-GIS Kependudukan sebagai Sumber Data Kependudukan dan Analisis Data Kependudukan. Materi yang disampaikan merupakan materi Geografi yang disajikan pada kelas XI tingkat SMA. Peserta berkempentingan dengan materi ini dikarena peserta akan menjadi subjek dari bonus demografi yang akan dihadapi oleh Indonesia. Jumlah usia tidak produktif ditanggung oleh penduduk usia produktif. hal ini akan menjadi ancaman jika sumber daya manusia tidak berkualitas, berdampak pada jumlah pengangguran dan kemiskinan.

\section{KESIMPULAN}

Pada proses pertumbuhan dan perkembangannya, remaja dihadapkan pada berbagai permasalahan. Tantangan yang dihadapi remaja di daerah pedesaan semakin besar. Salah satu permasalahan yang terjadi yakni pernikahan usia muda, rendahnya Pendidikan kependudukan dan Kesehatan reproduksi. Program ini menjadi langkah strategis sebagai upaya dalam meminimalisir permasalahan remaja di dearah pedesaan, Pelaksanaan program ini dilaksanakan selama dua hari dengan jumlah bobot materi sebanyak 20 jam. Dalam pelaksanaan program ini, melibatkan 4 pemateri yakni Alfyananda Kurnia Putra, M.Pd, Ifan Deffinika, M.Sc, Syahroni Al-Khadir, Daniar Arshita. Materi dalam program ini meliputi Paradigma Pendidikan Kependudukan di Indonesia, Kesehatan Reproduksi Generasi Z, Remaja Generasi Berencana (GenRe), Opportunities And Challenges: Towards The 2030 Indoneisa Demography Bonus, dan Penggunaan Web-GIS Kependudukan sebagai Sumber Data Kependudukan dan Analisis Data Kependudukan 


\section{DAFTAR PUSTAKA}

Binik, O., Ceretti, A., Cornelli, R., Schadee, H., Verde, A., \& Gatti, U. (2019). Neighborhood Social Capital, Juvenile Delinquency, and Victimization: Results from the International Self-Report Delinquency Study - 3 in 23 Countries. European Journal on Criminal Policy and Research, 25(3), 241-258. https://doi.org/10.1007/s10610-018-9406-1

Chapman, B. B., Brönmark, C., Nilsson, J. Å., \& Hansson, L. A. (2011). The ecology and evolution of partial migration. Oikos, 120(12), 1764-1775. https://doi.org/10.1111/j.1600-0706.2011.20131.x

Demir-Dagdas, T. (2020). Parental Divorce, Parent-Child Ties, and Health: Explaining Long-Term Age Differences in Vulnerability. Marriage and Family Review, 1-19. https://doi.org/10.1080/01494929.2020.1754318

He, Y., Zhou, G., Tang, C., Fan, S., \& Guo, X. (2019). The spatial organization pattern of urban-rural integration in urban agglomerations in China: An agglomeration-diffusion analysis of the population and firms. Habitat International, 87, 54-65. https://doi.org/10.1016/j.habitatint.2019.04.003

Isnaini, N., \& Sari, R. (2019). Pengetahuan Remaja Putri Tentang Dampak Pernikahan Dini pada Kesehatan Reproduksi di SMA Budaya Bandar Lampung. Jurnal Kebidanan Malahayati, 13(1), 21-26. https://doi.org/10.33024/jkm.v5i1.1338

lyer, P., \& Aggleton, P. (2013). "Sex education should be taught, fine...but we make sure they control themselves": teachers' beliefs and attitudes towards young people's sexual and reproductive health in a Ugandan secondary school. Sex Education, 13(1), 40-53. https://doi.org/10.1080/14681811.2012.677184

Lestari, P. (2012). Fenomena Kenakalan Remaja Di Indonesia. HUMANIKA, 12(1). https://doi.org/10.21831/hum.v12i1.3649

Menéndez Santurio, J. I., Fernández-Río, J., Cecchini Estrada, J. A., \& González-Víllora, S. (2020). Connections between bullying victimization and satisfaction/frustration of adolescents' basic psychological needs. Revista de Psicodidáctica (English Ed.). https://doi.org/10.1016/j.psicoe.2019.11.002

Mochaoa Rogers, M., Mfeka-Nkabinde, G., \& Ross, A. (2019). An evaluation of male learners' knowledge, attitudes and practices regarding sexual and reproductive health in rural northern KwaZulu-Natal province. South African Family Practice, 61(6), 239-245. https://doi.org/10.1080/20786190.2019.1664539

Murry, V. M., Cooper, S. M., Burnett, M., \& Inniss-Thompson, M. N. (2020). Rural African Americans' Family Relationships and Well-Being (pp. 169-200). https://doi.org/10.1007/978-3-030-376895_7

Pandey, P. L., Seale, H., \& Razee, H. (2019). Exploring the factors impacting on access and acceptance of sexual and reproductive health services provided by adolescent-friendly health services in Nepal. PLoS ONE, 14(8). https://doi.org/10.1371/journal.pone.0220855

Paolini, A. (2019). Social Emotional Learning: Role of the School Counselor in Promoting College and Career Readiness. Anatolian Journal of Education, 5(1), 125-134. https://doi.org/10.29333/aje.2019.411a

Rimmer, M. A., Sugama, K., Rakhmawati, D., Rofiq, R., \& Habgood, R. H. (2013). A review and SWOT analysis of aquaculture development in Indonesia. Reviews in Aquaculture, 5(4), 255-279. https://doi.org/10.1111/raq.12017

Santhya, K. G., \& Jejeebhoy, S. J. (2015). Sexual and reproductive health and rights of adolescent girls: Evidence from low- and middle-income countries. Global Public Health, 10(2), 189-221. https://doi.org/10.1080/17441692.2014.986169

Steeg, S., Carr, M. J., Mok, P. L. H., Pedersen, C. B., Antonsen, S., Ashcroft, D. M., Kapur, N., Erlangsen, A., Nordentoft, M., \& Webb, R. T. (2020). Temporal trends in incidence of hospitaltreated self-harm among adolescents in Denmark: national register-based study. Social Psychiatry and Psychiatric Epidemiology, 55(4), 415-421. https://doi.org/10.1007/s00127-01901794-8 
Sulfemi, W. B. (2018). Penggunaan Metode Demontrasi dan Media Audio Visual dalam Meningkatkan Hasil Belajar Peserta Didik Mata Pelajaran IPS. Jurnal Pendas Mahakam, 3(2), 151-158. https://doi.org/10.31227/osf.io/qrhsf

Widoyoko Tayibnapis, F. Y. (2000). Evaluasi Program Pembelajaran. Jurnal Ilmu Pendidikan, 238.

Wiradimadja, A., Kurniawan, B., \& Sukamto. (2019). PELATIHAN DAN PENDAMPINGAN

PENYUSUNAN PTK (PENELITIAN TINDAKAN KELAS) BAGI GURU IPS SMP/MTS

MALANG RAYA. Jurnal Praksis Dan Dedikasi Sosial (JPDS), 2(1).

Zahriani, Z. (2014). Kontektualisasi Direct Instruction Dalam Pembelajaran Sains. Lantanida Journal, 2(1), 95-106. https://doi.org/10.22373/lj.v2i1.667

Zangiacomi Martinez, E., \& da Roza, D. L. (2020). Ecological analysis of adolescent birth rates in Brazil: Association with Human Development Index. Women and Birth, 33(2), e191-e198. https://doi.org/10.1016/j.wombi.2019.04.002 